\title{
Deglaciation of the Caucasus Mountains, Russia/Georgia, in the 21st century observed with ASTER satellite imagery and aerial photography
}

\author{
M. Shahgedanova ${ }^{1}$, G. Nosenko $^{2}$, S. Kutuzov ${ }^{1,2}$, O. Rototaeva ${ }^{2}$, and T. Khromova ${ }^{2}$ \\ ${ }^{1}$ Department of Geography and Environmental Science and Walker Institute for Climate System Research, \\ University of Reading, Whiteknights, Reading RG6 6AB, UK \\ ${ }^{2}$ Laboratory of Glaciology, Institute of Geography, Russian Academy of Sciences, 29 Staromonetny Pereulok, Moscow, \\ 119017, Russia
}

Correspondence to: M. Shahgedanova (m.shahgedanova@reading.ac.uk)

Received: 10 July 2014 - Published in The Cryosphere Discuss.: 25 July 2014

Revised: 5 December 2014 - Accepted: 9 December - Published: 16 December 2014

\begin{abstract}
Changes in the map area of 498 glaciers located on the Main Caucasus ridge (MCR) and on Mt. Elbrus in the Greater Caucasus Mountains (Russia and Georgia) were assessed using multispectral ASTER and panchromatic Landsat imagery with $15 \mathrm{~m}$ spatial resolution in 1999/2001 and 2010/2012. Changes in recession rates of glacier snouts between 1987-2001 and 2001-2010 were investigated using aerial photography and ASTER imagery for a sub-sample of 44 glaciers. In total, glacier area decreased by $4.7 \pm 2.1 \%$ or $19.2 \pm 8.7 \mathrm{~km}^{2}$ from $407.3 \pm 5.4 \mathrm{~km}^{2}$ to $388.1 \pm 5.2 \mathrm{~km}^{2}$. Glaciers located in the central and western MCR lost $13.4 \pm 7.3 \mathrm{~km}^{2}(4.7 \pm 2.5 \%)$ in total or $8.5 \mathrm{~km}^{2}(5.0 \pm 2.4 \%)$ and $4.9 \mathrm{~km}^{2}(4.1 \pm 2.7 \%)$ respectively. Glaciers on Mt. Elbrus, although located at higher elevations, lost $5.8 \pm 1.4 \mathrm{~km}^{2}(4.9 \pm 1.2 \%)$ of their total area. The recession rates of valley glacier termini increased between 19872000/01 and 2000/01-2010 (2000 for the western MCR and 2001 for the central MCR and Mt. Elbrus) from $3.8 \pm 0.8$, $3.2 \pm 0.9$ and $8.3 \pm 0.8 \mathrm{~m} \mathrm{yr}^{-1}$ to $11.9 \pm 1.1,8.7 \pm 1.1$ and $14.1 \pm 1.1 \mathrm{~m} \mathrm{yr}^{-1}$ in the central and western MCR and on Mt. Elbrus respectively. The highest rate of increase in glacier termini retreat was registered on the southern slope of the central MCR where it has tripled. A positive trend in summer temperatures forced glacier recession, and strong positive temperature anomalies in 1998, 2006, and 2010 contributed to the enhanced loss of ice. An increase in accumulation season precipitation observed in the northern MCR since the mid-1980s has not compensated for the effects of sum-
\end{abstract}

mer warming while the negative precipitation anomalies, observed on the southern slope of the central MCR in the 1990s, resulted in stronger glacier wastage.

\section{Introduction}

Shrinkage of mountain glaciers in response to the observed climatic warming has been documented worldwide. The 1990s and 2000s were the warmest decades in the 150-year instrumental record (IPCC, 2013; see their Fig. 2.19), with global surface temperature anomalies of 0.24 and $0.44^{\circ} \mathrm{C}$ above the $1961-1990$ mean respectively (www.metoffice.gov.uk/research/monitoring/climate/ surface-temperature). Mountain glaciers are sensitive indicators of climatic change at the decadal timescale (Hoelzle et al., 2003), and acceleration in their area and volume reduction in the 1990s has been reported for many regions (Dyurgerov and Meier, 2000; Zemp et al., 2009). The contribution of glaciers and ice caps (excluding Antarctica and Greenland) to the global sea level budget increased from $0.67 \pm 0.03 \mathrm{~mm} \mathrm{yr}^{-1}$ in $1972-2008$ to $0.99 \pm 0.04 \mathrm{~mm} \mathrm{yr}^{-1}$ in 1993-2008, in line with intensifying climatic warming and glacier melt (Church et al., 2012).

Remote sensing is an established way of monitoring changes in glacier area and positions of glacier snouts. To date, most assessments have been conducted using multispectral Landsat Thematic Mapper (TM) and Enhanced Thematic Mapper Plus (ETM+) imagery, with $30 \mathrm{~m}$ horizontal 


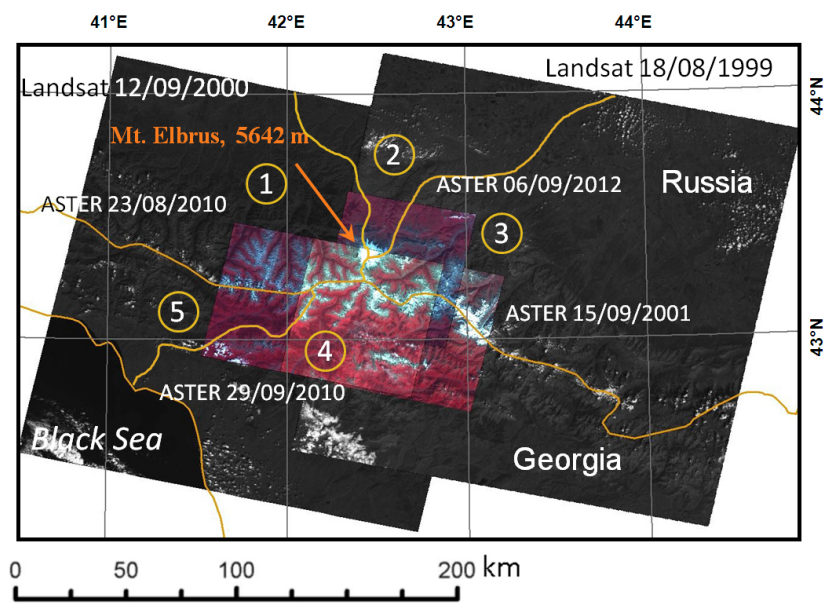

Figure 1. Study area and satellite imagery used for the analysis. The yellow lines show the Black Sea coastline, the MCR, and the catchment boundaries. The catchments are numbered as follows: (1) Kuban; (2) Malka; (3) Baksan; (4) Inguri; and (5) Kodori.

resolution available since 1982 and 1999 respectively, and Advanced Spaceborne Thermal Emission and Reflection Radiometer (ASTER) imagery with $15 \mathrm{~m}$ resolution available since 2000. Together with historical aerial photographs and maps, this imagery enabled assessments at time steps of 20-50 years during which the magnitude of glacier change significantly exceeded measurement errors. Various studies that used Landsat imagery reported measurement errors from about $3-5 \%$ of single-glacier area change for clear ice (with larger errors for smaller glaciers) to over $10 \%$ for debriscovered glaciers or those whose outlines merge with snow fields (e.g. Andreassen et al., 2008; Paul and Andreassen, 2009; Bhambri et al., 2011; Paul et al., 2013). For this reason, assessments at shorter intervals in most regions required data from repeated aerial surveys or finer-resolution satellite imagery whose spatial extent and availability are limited (e.g. Hall et al., 2003). Now that high-resolution multispectral ASTER imagery has been available for more than a decade, its consistent use should significantly reduce uncertainties in measurements of glacier change and enable assessments at decadal intervals over wider regions.

One of the main centres of mountain glaciation in Europe is the Greater Caucasus Mountains located between the Black and Caspian Seas in the densely populated southwest of Russia and Georgia (Fig. 1). Few studies of the Caucasus glaciers have examined large samples using consistent methods and data. In the Russian-language literature, the most detailed assessments are those by Panov (1993) and Yefremov et al. (2007) based predominantly on repeated field measurements of positions of glacier termini in the Main (Glavny) Caucasus ridge (MCR). In the English-language literature, Stokes et al. (2006) examined changes in termini positions of 113 glaciers in the central Greater Caucasus between 1985 and 2000 using satellite imagery. The Panov (1993) analysis of the field measurements and data derived from analysis of historical maps showed that in the period between 1933 and $1965 / 70$ glacier termini in the MCR retreated at an average rate of $12.3 \mathrm{~m} \mathrm{yr}^{-1}$ while in the period between $1965 / 70$ and $1986 / 89$ the recession slowed down to $6.1 \mathrm{~m} \mathrm{yr}^{-1}$. In the former assessment period, glaciers of the northern and southern slopes retreated at the same rate while in the latter period, the retreat rate of $8.9 \mathrm{~m} \mathrm{yr}^{-1}$ observed on the southern slope exceeded the retreat rate of $4.8 \mathrm{~m} \mathrm{yr}^{-1}$ observed on the northern slope. Stokes et al. (2006) reported average glacier termini recession rates of $8 \mathrm{~m} \mathrm{yr}^{-1}$ between 1985 and 2000 . From this assessment, they inferred a total loss of bare ice area of about $10 \%$, but the study did not assess changes in areas of individual glaciers. Yefremov et al. (2007) reported similar results based on field measurements. Both Stokes et al. (2006) and Yefremov et al. (2007) reported acceleration of glacier retreat in the 1990s although Yefremov et al. (2007) stressed equally high recession rates in the mid-20th century and slowdown in glacier retreat between 1965 and 1985 in line with the earlier work by Panov (1993).

Other studies focused on changes in area and fluctuation of termini of individual or small samples of glaciers. Popovnin and Petrakov (2005) provided a detailed history of shrinkage of the Djankuat glacier in the central sector of the MCR between 1968 and 1999, reporting 9\% $\left(0.29 \% \mathrm{yr}^{-1}\right)$ shrinkage. Kutuzov et al. (2012) examined changes in the Marukh glacier located in the western MCR showing that area reduction was similar at $17 \%$ between 1945 and 2011 $\left(0.25 \% \mathrm{yr}^{-1}\right)$. Bushueva and Solomina (2012) examined recession of the Kaskatash glacier in the central MCR showing acceleration of its snout retreat rate from $1.8 \mathrm{~m} \mathrm{yr}^{-1}$ between 1971 and 1987 to $7.5 \mathrm{~m} \mathrm{yr}^{-1}$ between 1987 and 2008. More recently, changes in the lengths of seven glaciers in the central Greater Caucasus over the last 200 years were analysed showing that over the period these glaciers retreated with the exception of 1910s-1920s and 1960s-1980s, and that the rate of retreat has increased since the 1990s (Leclercq et al., 2014).

Changes in glacierized area on Mt. Elbrus, the largest glacierized massif in the Caucasus Mountains (Fig. 1), were examined by Zolotarev and Kharkovets (2007), who reported glacier shrinkage between 1957 and 1997. More recently, Zolotarev and Kharkovets (2012) extended these assessments to 2007 using data from field measurements, aerial photography, and high-resolution Cartosat-1 imagery. According to their assessments, the total glacierized area on Mt. Elbrus decreased from $132.51 \mathrm{~km}^{2}$ in 1957 to $120.03 \mathrm{~km}^{2}$ in 2007. Glacierized area decreased by $0.22 \mathrm{~km}^{2} \mathrm{yr}^{-1}$ between 1957 and 1979 , by $0.16 \mathrm{~km}^{2} \mathrm{yr}^{-1}$ between 1979 and 1997 , and by $0.45 \mathrm{~km}^{2} \mathrm{yr}^{-1}$ between 1997 and 2007. Another assessment of glacier change on Mt. Elbrus was published by Holobaca (2013), reporting area change of $9.1 \%$ between 1985 and 2007 from Landsat TM imager.

Continuous observations of glacier mass balance are conducted at two reference glaciers, Djankuat and Garabashi 
Table 1. Details of the imagery used for glacier mapping. Location of catchments are shown in Fig. 1.

\begin{tabular}{|c|c|c|c|}
\hline Date & Type of imagery & Region & No. of glaciers \\
\hline $6 / 09 / 2012$ & ASTER & $\begin{array}{l}\text { Mt. Elbrus } \\
42.96-43.60^{\circ} \mathrm{N}, 42.16-43.05^{\circ} \mathrm{E}\end{array}$ & \multirow[t]{2}{*}{20} \\
\hline 18/08/1999 & $\begin{array}{l}\text { Landsat ETM+ } \\
\text { panchromatic; path } \\
171 \text {; row } 030\end{array}$ & $\begin{array}{l}\text { Mt. Elbrus } \\
41.14-44.19^{\circ} \mathrm{N}, 41.94-44.96^{\circ} \mathrm{E}\end{array}$ & \\
\hline $\begin{array}{l}15 / 09 / 2001 \\
29 / 09 / 2010\end{array}$ & $\begin{array}{l}\text { ASTER } \\
\text { ASTER }\end{array}$ & $\begin{array}{l}\text { Central MCR and Mt. Elbrus for } \\
\text { the assessment of recession of } \\
\text { glacier termini; } \\
43.05-43.35^{\circ} \mathrm{N}, 42.34-42.83^{\circ} \mathrm{E}\end{array}$ & $\begin{array}{l}174 \text { in all: } 99,9 \text {, and } 69 \text { on northern and } \\
\text { southern slopes in Baksan, Malka and } \\
\text { Inguri catchments respectively }\end{array}$ \\
\hline $\begin{array}{l}23 / 08 / 2010 \\
12 / 09 / 2000\end{array}$ & $\begin{array}{l}\text { ASTER } \\
\text { Landsat ETM+ } \\
\text { panchromatic; path } \\
171 \text {; row } 030\end{array}$ & $\begin{array}{l}\text { Western MCR; } 43.07-43.43^{\circ} \mathrm{N} \text {, } \\
41.62-42.40^{\circ} \mathrm{E}\end{array}$ & $\begin{array}{l}304 \text { in all: } 147 \text { on northern (Kuban } \\
\text { catchment) and } 157 \text { on southern (Inguri } \\
\text { and Kodori catchments) slopes }\end{array}$ \\
\hline $25-26 / 09 / 1987$ & Aerial photographs & $43.05-43.35^{\circ} \mathrm{N}, 42.34-42.83^{\circ} \mathrm{E}$ & $\begin{array}{l}28 \text { glaciers: } 7 \text { in the Baksan and Adylsu } \\
\text { valleys, } 14 \text { in the Inguri valley in central } \\
\text { MCR, and } 6 \text { on southeastern slope of Mt. } \\
\text { Elbrus }\end{array}$ \\
\hline 25-26/09/ 1987 & Aerial photographs & $43.07-43.43^{\circ} \mathrm{N}, 41.80-42.40^{\circ} \mathrm{E}$ & $\begin{array}{l}17 \text { glaciers in the Kuban, Kodori, and } \\
\text { Inguri basins in the western MCR }\end{array}$ \\
\hline
\end{tabular}

(WGMS, 2013). Strong reductions in cumulative mass balance were registered at both since 1995, providing further evidence of glacier wastage (Popovnin, 2000; Popovnin and Petrakov, 2005; Shahgedanova et al., 2005, 2007; Rototaeva et al., 2006; Dolgova et al., 2013).

While published assessments suggest that glaciers in the Greater Caucasus are retreating and rates of retreat have accelerated at the end of the 20th century, reliable large-scale assessments of changes in map areas of glaciers are not available with the exception of those by Zolotarev and Kharkovets (2007, 2012) for Mt. Elbrus.

This paper has two objectives: (i) to quantify changes in glacier map area in the central and western sectors of the Greater Caucasus Mountains between 1999/2001 and 2010/2012 using ASTER imagery (or, where not available, $15 \mathrm{~m}$ resolution panchromatic Landsat imagery) in line with the requirements of the Global Land Ice Measurements from Space (GLIMS) project (http://www.glims.org/) and (ii) to assess changes in glacier retreat rates from the end of the 20th century to the end of the first decade of the 21 st century using aerial photographs from 1987 and ASTER imagery for a sub-sample of valley glaciers. Glacier snout recession is a more sensitive indicator of changes at decadal timescale than area change (Hoelzle et al., 2003; Koblet et al., 2010; Bhambri et al., 2012; Leclercq and Oerlemans, 2012; Leclercq et al., 2014), especially for the large glacierized massifs such as Mt. Elbrus. Valley glaciers were selected for the assessment because they exhibit the clearest climatic signal, being less dependent on avalanche nourishment and topography than other types of glaciers (e.g. Shahgedanova et al., 2012).

\section{Study region}

According to the Catalogue of Glaciers of the USSR (Panov and Kravtsova, 1967; Borovik and Kravtsova, 1970; Maruashvili et al., 1975) and the World Glacier Inventory (WGI), the Greater Caucasus accommodated over 2000 glaciers with a combined area of approximately $1600 \mathrm{~km}^{2}$ in the $1960 \mathrm{~s}-$ 1980s (http://nsidc.org/data/glacier_inventory/). Very close results were obtained by Nakano et al. (2013) from Landsat imagery. GLIMS and Randolph Glacier Inventory (www. glims.org) quote over 1300 glaciers with a combined area of $1354 \mathrm{~km}^{2}$. The difference is due to the omission of the smaller glaciers in the eastern sector of the Caucasus Mountains in this recent assessment.

The Greater Caucasus is subdivided into western, central, and eastern sectors which have average elevations of 3200,4100 , and $3700 \mathrm{~m}$ respectively. The most elevated central sector extends between Mt. Elbrus (5642 m a.s.l.; Fig. 1) located several km north of the MCR and Mt. Kazbek (5033 $\mathrm{m}$ a.s.1.; $\left.42.7^{\circ} \mathrm{N}, 44.52^{\circ} \mathrm{E}\right)$. A characteristic feature of the Greater Caucasus is a strong west-east precipitation gradient. The southern slope of the western MCR receives over $2000 \mathrm{~mm}$ of precipitation while in the east, the annual total is about 10 times lower (Volodicheva, 2002). In response to the west-east precipitation gradients, the equilibrium line al- 

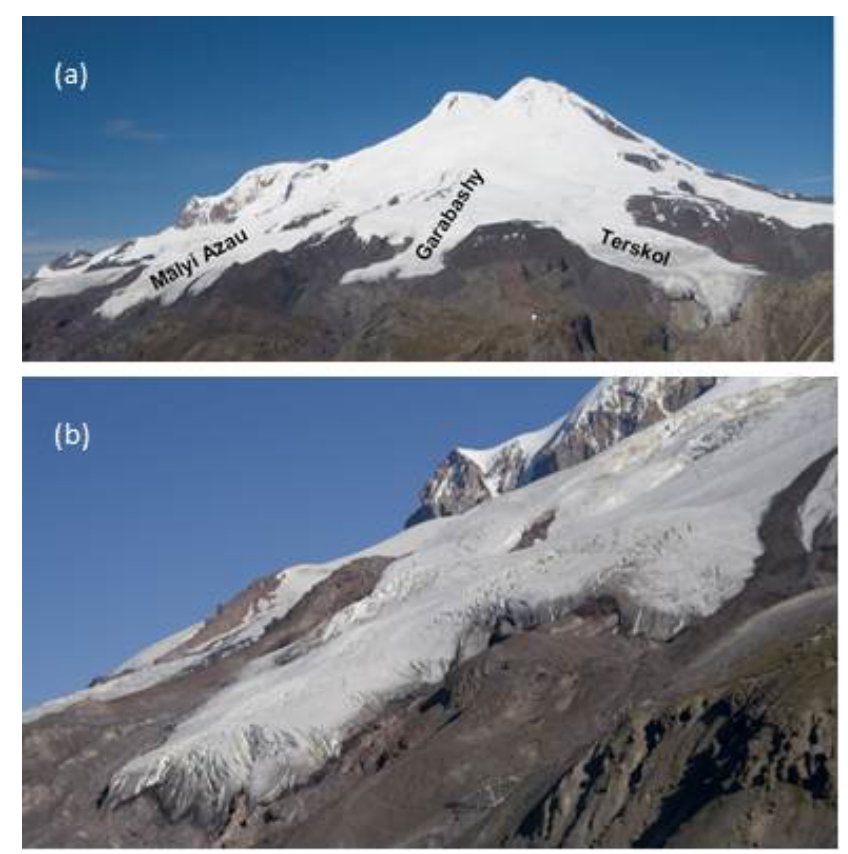

Figure 2. Oblique aerial photograph of (a) glaciers on Mt. Elbrus and (b) snout of the Malyi Azau glacier. Note the clearly defined glacier boundaries and a very limited extent of debris cover. Photograph by I. I. Lavrentiev (25 August 2009).

titude (ELA) changes rising from $2500-2700 \mathrm{~m}$ in the west to about $3200-3400 \mathrm{~m}$ in the central sector to $3700-3950 \mathrm{~m}$ in the east. Due to greater precipitation in the south, ELA is lower on the southern slopes especially in the central MCR and on Mt. Elbrus, where differences between the southern and northern slopes reach 1000 and $200-300 \mathrm{~m}$ respectively (Rototaeva et al., 2006).

The largest glaciers are located in the central Greater Caucasus including the glaciated massif of Mt. Elbrus. A number of larger valley glaciers have individual areas of $3-36 \mathrm{~km}^{2}$. Cirque glaciers with individual areas of $1 \mathrm{~km}^{2}$ or less account for approximately $40 \%$ of the total. In the western and eastern sectors, cirque glaciers with individual areas less than $3 \mathrm{~km}^{2}$ prevail (Rototaeva et al., 2006).

\section{Data and methods}

Changes in glacierized area and recession rates of glacier termini were assessed for the central and western sectors of the MCR and Mt. Elbrus (Table 1; Fig. 1). Areas of 498 glaciers were mapped, of which 174 and 304 were located in the central and western sectors of the MCR, respectively, on both the northern (Russia) and southern (Georgia) slopes and 20 were on Mt. Elbrus (Table 1). The size of the smallest glacier mapped was $0.02 \mathrm{~km}^{2}$.

Glacier outlines were mapped manually despite the advantages of automated mapping demonstrated by Paul et

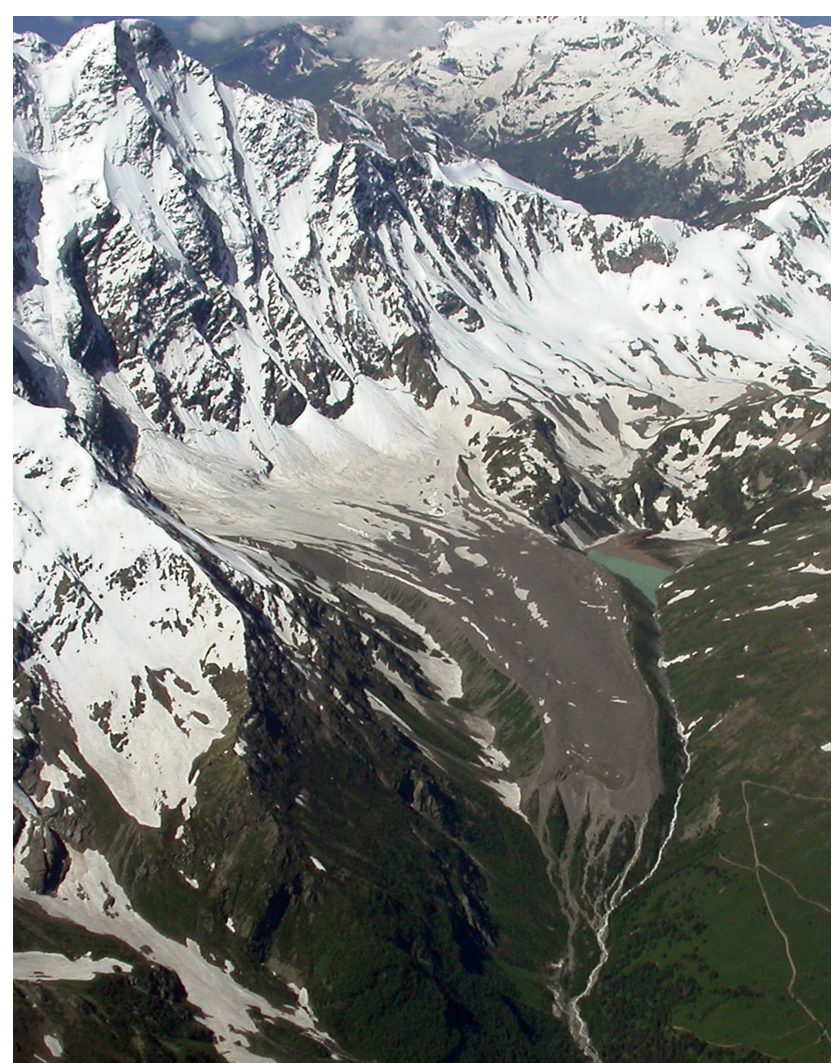

Figure 3. Oblique aerial photograph of the Donguz-Orun glacier which has the highest extent of debris cover in the sample. Photograph by I. I. Lavrentiev (25 August 2009).

al. $(2009,2013)$ because of the failure of the shortwave infrared (SWIR) channel used in automated classifications (Paul et al., 2002; Bolch et al., 2010) on ASTER in April 2008. Potential relative error strongly increases with decreasing glacier area and manual corrections are required when automatically mapping small glaciers because automated techniques tend to omit mixed (clear ice-debris cover) pixels along the glacier perimeter, resulting in a systematic negative bias in glacier area calculation. Paul et al. (2013) and Fischer et al. (2014) have shown that the bias significantly increases for glaciers with areas less than $1 \mathrm{~km}^{2}$ (which constitute about $85 \%$ of all glaciers in the Caucasus) reducing the advantages of automated techniques.

\subsection{Satellite imagery and glacier area mapping}

Two ASTER scenes from 2001 and 2010 were used for glacier mapping in the central MCR (Table 1). ASTER imagery from 2010 was used for mapping glaciers in the western MCR, however, earlier cloud-free imagery was not available and a Landsat ETM+ panchromatic image from 2000, which has the same resolution of $15 \mathrm{~m}$ as ASTER, was used instead. For Mt. Elbrus, an ASTER scene was used for 2012 and panchromatic Landsat ETM+ was used for 1999 because 
these are the only higher-resolution cloud-free images which cover the whole of Mt. Elbrus. An ASTER 2001 scene, used for mapping in the central MCR, covers only the southeastern sector of Mt. Elbrus. To aid glacier mapping, a vast database of ground-based and aerial oblique photographs was used (e.g. Figs. 2, 3).

The ASTER images were supplied by NASA Land Processes Distributed Active Archive Center (LP DAAC), and Landsat ETM+ panchromatic images were downloaded from the US Geological Survey (USGS; http://glovis.usgs. gov/). Both were supplied in the Universal Transverse Mercator (UTM) zones 36-38 WGS 84 projection. The ASTER images were orthorectified prior to the distribution (Lang and Welch, 1999). All satellite images were acquired under (nearly) cloud-free conditions at the end of the ablation season (Table 1), when glacier tongues were free of seasonal snow. On ASTER images, glacier outlines were mapped using the $0.52-0.6,0.63-0.69$, and $0.78-0.86 \mu \mathrm{m}$ bands. Where glacier margins were obscured by shadows from rocks and glacier cirque walls, a contrast-stretching function was applied to the imagery using ENVI 4.6 software.

Most glaciers, except those located on Mt. Elbrus, have clearly defined ice divides. To avoid errors associated with delineation of the upper boundaries of glaciers located on Mt. Elbrus, the total glacierized area of the Elbrus massif was mapped and reported as the main outcome of this study. To assess changes in individual glaciers, the ASTER GDEM and the hydrological tools for basin delineation available in ARC 10.1 GIS and applied previously by Schiefer et al. (2008), Paul and Andreassen (2009), Svoboda and Paul (2009), Bolch et al. (2010), and Keinholz et al. (2013) were used for glacier delineation. It was assumed that the upper boundaries of glaciers on Mt. Elbrus did not change between 1999 and 2012.

Within the study area, five glaciers have been identified as surging by Rototaeva (2006). These glaciers were excluded from the analysis with the exception of the Kyukyurtlyu glacier located on Mt. Elbrus. Although this glacier can exhibit changes that are not forced by climatic variations, there was no evidence of surging within the assessment period. Of the remaining four, three glaciers did not exhibit measurable change within the assessment period and one (Cheget-Kara) lost $0.04 \mathrm{~km}^{2}$ or $1.5 \%$ of its area despite advancing by approximately $40 \mathrm{~m}$ between 2000 and 2003 (Rototaeva, 2006).

\subsection{Quantification of errors}

For each glacier located in the MCR, we calculated three error terms resulting from (i) co-registration of images, (ii) identification of glacier margins, and (iii) presence of debris cover on glacier snouts.

The ASTER images, used for mapping glaciers in the central sector of the MCR, and ASTER and panchromatic Landsat ETM+ images, used for mapping in the western sector of the MCR and Mt. Elbrus, were co-registered using a network of 12 ground control points (GCP) for each pair of images. Although ASTER imagery was used for both 2001 and 2010, co-registration of these images and calculation of the resulting error term were required because different digital elevation models (DEMs) were used in 2001 and 2010 (Meyer et al., 2011). The maximum root-mean-square error $\left(\mathrm{RMSE}_{x, y}\right)$ was $8.1 \mathrm{~m}$, which is less than the size of an ASTER pixel. The error of co-registration was calculated following Granshaw and Fountain (2006). A buffer, with a width of half of the $\mathrm{RMSE}_{x, y}$ was created along the glacier outlines and the error term was calculated as an average ratio of the original glacier areas to the areas with a buffer increment, resulting in an average error of $\pm 1.2 \%$. The errors of co-registration of the ASTER and panchromatic Landsat ETM+ images used for mapping glaciers in the western MCR and on Mt. Elbrus were calculated using a similar method. In the western Caucasus, $\mathrm{RMSE}_{x, y}$ of $8.3 \mathrm{~m}$ and the error of $\pm 1.4 \%$ were achieved, while on Mt. Elbrus, where the glacierized area is an order of magnitude larger than the size of individual glaciers in the MCR, the error was $\pm 0.7 \%$.

The uncertainty of glacier margin identification was estimated using multiple digitization following Paul et al. (2013). A sub-sample of twenty glaciers from the MCR with areas of $0.5-9.8 \mathrm{~km}^{2}$ was re-digitized 10 times by three different operators. The average error was calculated as $1.3 \%$ and used for the central and western MCR sub-samples. The error for the Elbrus glacierized massif as a whole was very small at $0.2 \%$ due to (i) its large size and (ii) detailed knowledge of the region obtained during many seasons of field work, including differential GPS (DGPS) surveys which have been conducted since 2008 on individual glaciers (unpublished field records) and recent helicopter surveys (e.g. Fig. 2).

Debris cover on glacier snouts is a major source of error in glacier mapping (Bhambri et al., 2011; Bolch et al., 2008; Racoviteanu et al., 2008; Frey et al., 2012; Paul et al., 2013). In the Caucasus, supra-glacial debris cover has a smaller extent than in many glacierized regions, especially Asia (Stokes et al., 2007). Importantly, debris cover is not continuous on the snouts of many glaciers in the MCR and most glaciers of Mt. Elbrus (Fig. 2). Most debris-covered snouts do not merge with periglacial landforms, exhibiting a marked change in topography, and are characterized by the presence of patches of clear ice and/or thermokarst, making identification of glacier margins on the satellite imagery easier.

To account for the error term due to debris cover, we followed Frey et al. (2012) and increased the buffer size to two pixels $(30 \mathrm{~m})$ for the debris-covered segments of those glaciers where supra-glacial debris was extensive. One of the most heavily debris-covered glaciers in the Caucasus is Donguz-Orun (glacier tongue coordinates $43.231^{\circ} \mathrm{N}$, $42.512^{\circ} \mathrm{E}$ ) where supra-glacial debris covers approximately $70 \%$ of the glacier as a result of avalanche nourishment supplying debris from the headwall exceeding $4400 \mathrm{~m}$ a.s.l. (Fig. 3). For this specific glacier, the error of mapping due to 
Table 2. Changes in glacierized area.

\begin{tabular}{llrrrrr}
\hline \multirow{2}{*}{ Region } & \multicolumn{2}{c}{ Combined area $\left(\mathrm{km}^{2}\right)$} & & \multicolumn{2}{c}{ Area reduction } \\
\cline { 3 - 4 } \cline { 7 - 8 } & & $1999 / 2000 / 2001$ & $2010 / 2012$ & & $\mathrm{~km}^{2}$ & $\%$ \\
\hline \multirow{2}{*}{ Central MCR } & Total & $170.6 \pm 2.3$ & $162.1 \pm 2.1$ & & $8.5 \pm 4.1$ & $5.0 \pm 2.4$ \\
& Northern & $73.4 \pm 1.1$ & $70.3 \pm 1.0$ & & $3.1 \pm 1.7$ & $4.3 \pm 2.3$ \\
& Southern & $97.2 \pm 1.2$ & $91.8 \pm 1.1$ & & $5.4 \pm 2.4$ & $5.6 \pm 2.5$ \\
\hline \multirow{2}{*}{ Western MCR } & Total & $118.3 \pm 2.1$ & $113.4 \pm 2.1$ & & $4.9 \pm 3.2$ & $4.1 \pm 2.7$ \\
& Northern & $63.2 \pm 1.1$ & $60.4 \pm 1.1$ & & $2.8 \pm 1.7$ & $4.4 \pm 2.7$ \\
& Southern & $55.2 \pm 1.0$ & $53.1 \pm 1.0$ & & $2.1 \pm 1.5$ & $3.8 \pm 2.7$ \\
\hline \multirow{2}{*}{ Elbrus } & & $118.4 \pm 1.0$ & $112.6 \pm 1.0$ & & $5.8 \pm 1.4$ & $4.9 \pm 1.2$ \\
\hline
\end{tabular}

Table 3. Area loss (\%) according to glacier type in the central and western MCR. Number of glaciers of each type is given in parentheses. The two compound-valley glaciers located on the southern slope of the central MCR are not included (see text).

\begin{tabular}{lrrrrrrrrr}
\hline \multirow{2}{*}{ Region } & \multicolumn{3}{c}{ Central } & & \multicolumn{2}{c}{ Western } & \multirow{2}{*}{ All } \\
\cline { 2 - 3 } Type & North & South & All & & North & South & \multirow{2}{*}{ All } & \\
\hline Valley & $5.3(7)$ & $7.4(25)$ & 6.7 & & $2.9(19)$ & $3.6(42)$ & 3.3 & 5.0 \\
Cirque & $4.1(156)$ & $3.3(20)$ & 4.0 & & $6.2(104)$ & $4.4(85)$ & 5.5 & 4.6 \\
Hanging & $4.5(4)$ & $0(3)$ & 4.4 & & $6.6(23)$ & $0.8(6)$ & 5.2 & 5.1 \\
Ice aprons & $5.9(7)$ & $6.8(15)$ & 6.1 & & $3.5(11)$ & $4.0(24)$ & 3.7 & 5.0 \\
\hline
\end{tabular}

debris cover was calculated as $\pm 4.7 \%$. We stress that (i) this glacier is not typical for the region and (ii) this is the largest error in the whole data set. The debris cover term was calculated for 67 glaciers and for most glaciers, it was below $\pm 1 \%$.

The total error of glacier area change was calculated as a root mean square of the co-registration, margin identification and, where applicable, debris-cover-related error terms.

\subsection{Assessment of changes in positions of glacier termini using aerial photographs}

Positions of the termini of 21 and 17 valley glaciers located in the central and western sectors of the MCR respectively and of 6 glaciers located on the southeastern slope of Mt. Elbrus were measured from the satellite images and from the aerial photographs from 1987 (Table 1). The number of measured valley glaciers (44 out of 97 in the sample) was restricted by the availability of suitable aerial photographs. Glacier length and slope are the main controls of glacier snout reaction (Hoelzle et al., 2003). All glaciers in the sample had similar slopes; the average lengths (measured along the central flow line) of glaciers and length ranges are shown in Table 5.

Twenty six and seventeen aerial photographs with a resolution of 1-3 m were obtained on 25-26 September 1987 under the nearly cloud-free conditions for central (including Mt. Elbrus) and western sectors of the Greater Caucasus respectively (Table 1). The photographs were digitized at
600 dpi resolution and co-registered to the 2001 ASTER and the 2000 Landsat ETM+ panchromatic images using 10-12 GCP per photograph. After co-registration, $\mathrm{RMSE}_{x, y}$ values not exceeding $6.5 \mathrm{~m}$ were achieved for both ASTER and Landsat. ASTER 2001 and 2010 images were used to map retreat of glacier termini on Mt. Elbrus to make the retreat rates comparable with the rest of the data set.

A change in glacier terminus position can be understood as a length measurement along a central flow line (e.g. Stokes et al., 2006). However, changes in position of glacier termini are not uniform along their margin. To account for this, five measurements were taken across the width of each glacier terminus along flow lines, and an average value was calculated in line with similar studies (e.g. Hall et al., 2003; Koblet et al., 2010; Bhambri et al., 2012). The uncertainty in terminus recession was calculated as a combination of the maximum $\mathrm{RMSE}_{x, y}$ of image co-registration (8.1 and $6.5 \mathrm{~m}$ for 2001-2010 and 1987-2001 periods in the central sector and 8.3 and $6.5 \mathrm{~m}$ in the western sector) and a one-half pixel size of the satellite images $(7.5 \mathrm{~m})$, resulting in total errors of \pm 11.0 and $\pm 9.9 \mathrm{~m}$ for the two assessment periods for the central sector and \pm 11.2 and $\pm 9.9 \mathrm{~m}$ for the western sector.

\subsection{Meteorological data}

There are two high-altitude meteorological stations with ongoing observations in the study area, Terskol in the central $\mathrm{MCR}\left(43.26^{\circ} \mathrm{N}, 2.51^{\circ} \mathrm{E} ; 2141 \mathrm{~m}\right.$ a.s.l.) and 
Klukhorski Pereval (pass) in the western sector $\left(43^{\circ} 15^{\prime} 8^{\prime \prime} \mathrm{N}\right.$, 41 49'39" E; $2037 \mathrm{~m}$ a.s.1.). Continuous records from these stations are available from 1951 and 1960 onwards, respectively. Their monthly air temperature and precipitation records were used to characterize climatic variations in the Baksan, Malka, and Kuban catchments on the northern slope. Continuous observations from the high-altitude regions of the Inguri and Kodori catchments are not available. Records from Abastumani station, located south of the study region $\left(41.77^{\circ} \mathrm{N}, 42.83^{\circ} \mathrm{E} ; 1265 \mathrm{~m}\right.$ a.s.l.), available for the $1951-$ 2005 period, were used to characterize changes on the southern slope of the central MCR.

\section{Results}

\subsection{Area change}

\subsubsection{The Main Caucasus ridge}

In total, 478 glaciers located in the central and western MCR lost $13.4 \mathrm{~km}^{2}$ or $4.7 \pm 2.1 \%$ of their map area between 2000/2001 and 2010 (Table 2). Glaciers in the central MCR lost $8.5 \mathrm{~km}^{2}$ or $5.0 \pm 2.4 \%$ of their area $\left(0.6 \% \mathrm{yr}^{-1}\right)$; in the western sector, the area decreased by $4.9 \mathrm{~km}^{2}$ or $4.1 \pm 2.7 \%$ $\left(0.4 \% \mathrm{yr}^{-1}\right)$. Overall, the differences between the slopes and sectors were small and within uncertainty of the measurements. The greatest loss was observed on the southern slope in the central MCR where glaciers lost $5.6 \pm 2.5 \%$ of their combined map area in 9 years and the lowest on the southern slope of the western MCR where glaciers lost $3.8 \pm 2.7 \%$, although we note that these differences are within the uncertainty margin. Of all glaciers in the sample, twenty lost over $20 \%$ of their $2000 / 2001$ areas and forty one glaciers lost between 10 and $20 \%$.

There are two compound-basin valley glaciers in the sample, both located in the Inguri catchment. They experienced a slower recession than glaciers of other types (Table 3), losing $2.80 \pm 1.8 \%$ of their areas. Both glaciers are among the largest in the sample with 2001 areas of $31.4 \mathrm{~km}^{2}$ (Lekzyri; the third largest glacier in the Caucasus Mountains and the largest in the sample) and $9.4 \mathrm{~km}^{2}$ (Chalaati). There are no statistically significant differences in area loss between other types of glaciers for the MCR as a whole, however, some differences between the northern and southern slopes and the sectors were just outside the uncertainty margin (Table 3). Thus the relative area loss by valley glaciers in the central sector of the MCR was twice as high as in the western sector and valley glaciers located on the southern slope of the central MCR lost the highest proportion of their map area in the whole sample. The valley glaciers in the central MCR are larger than in the west, and while their higher absolute loss $\left(4.6 \mathrm{~km}^{2}\right.$ against $1.9 \mathrm{~km}^{2}$ in the west) is expected, a higher relative loss is not in line with trends observed in other re-

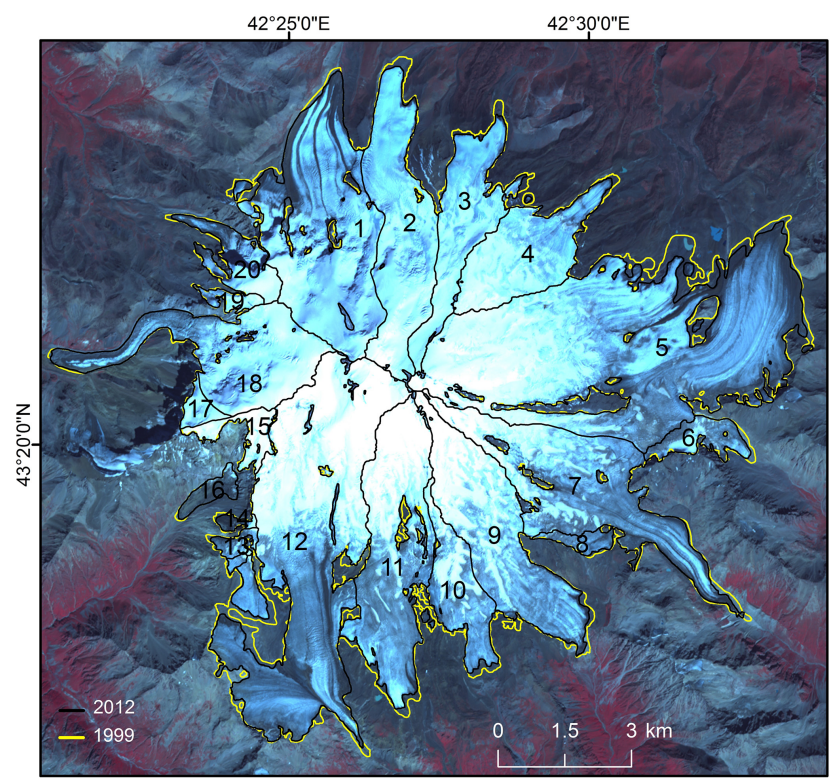

Figure 4. Changes in glacierized area of Mt. Elbrus between 1999 and 2012. See Table 4 for the statistics of changes in areas of individual glaciers. The 1999 Landsat ETM+ image (Table 1) is used as background.

gions and is likely to result from lower precipitation in the central MCR in comparison with the west (see Fig. 6).

In contrast to other glacierized regions (e.g. Paul et al., 2004; Citterio et al., 2007) and in rare agreement with DeBeer and Sharp (2007), the smallest glaciers exhibited the lowest relative change in the central MCR. Thus glaciers with 2001 map areas of $0.02-0.1 \mathrm{~km}^{2}$ lost in total $0.9 \pm 3.0 \%$ of their combined area; this loss resulted from a $33 \%$ reduction in area of a single glacier while another 36 did not exhibit measurable change. Glaciers within the $0.1-1.0$ and $1.0-5.0 \mathrm{~km}^{2}$ categories lost $5.2 \pm 2.2 \%$. Those larger than $5 \mathrm{~km}^{2}$ lost $3.7 \%$. In the western MCR, the difference was less marked and within the uncertainty margin. Glaciers with 2000 map areas of $0.02-0.1 \mathrm{~km}^{2}$ lost in total $3.9 \%$ of their combined area which is higher than in the central sector despite higher precipitation. Glaciers with 2000/2001 map areas of $0.1-1.0$ and $1.0-3.0 \mathrm{~km}^{2}$ lost 4.7 and $3.2 \%$ respectively.

\subsubsection{Mt. Elbrus}

Glaciers located on Mt. Elbrus lost $5.8 \pm 1.4 \mathrm{~km}^{2}$ or $4.9 \pm 1.2 \%\left(0.4 \% \mathrm{yr}^{-1}\right)$ of their combined area between 1999 and 2012. Their recession rate is comparable with glacier area loss in the MCR despite the higher elevation and larger accumulation-to-ablation area ratios (AAR) of the Elbrus glaciers (Table 4; Fig. 4). A characteristic feature of glacier recession on Mt. Elbrus is the expansion of nunataks, exposed rocks, and separation of sections of glaciers in the ablation zone below approximately $4000 \mathrm{~m}$ 


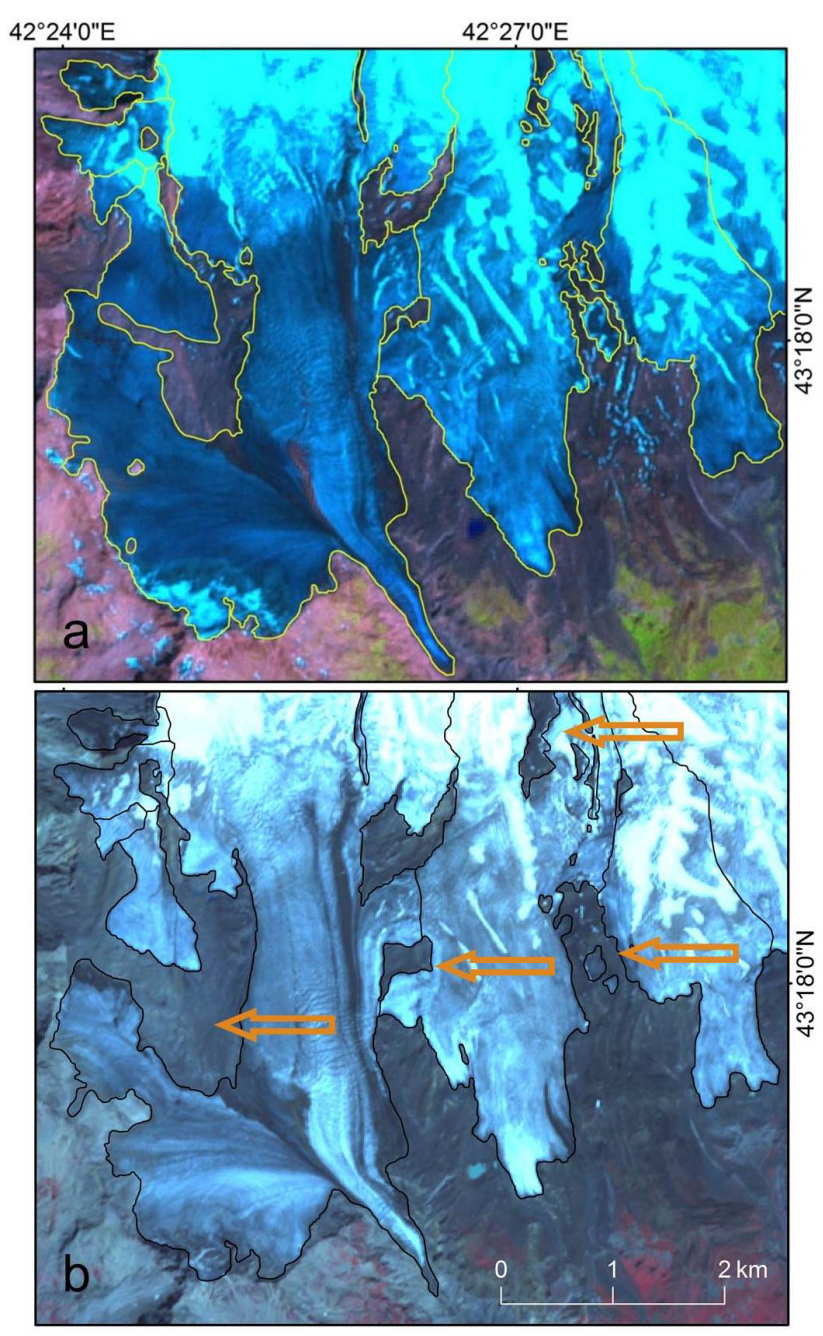

Figure 5. Expansion of exposed rocks on the southern slope of Mt. Elbrus: (a) 1999 and (b) 2012. Arrows point at the expanded areas of exposed rocks. The 1999 Landsat ETM+ image (Table 1) is used as background.

a.s.l. Nunataks and exposed rocks were not accounted for in the previous measurements (e.g. Zolotarev and Kharkovets, 2012) although their combined area was $4.1 \mathrm{~km}^{2}$ or $3.5 \%$ of the Elbrus glaciated massif in 1999. In 2012, their combined area was $3.7 \mathrm{~km}^{2}$. However, the reduction in their absolute area is misleading because in the lower parts of the ablation zone they merged with the surrounding rocks. Calculated relative to the boundaries of glaciated area as in 1999, the area of nunataks and exposed rocks was approximately $6 \mathrm{~km}^{2}$. Figure 5 illustrates the expansion of exposed rocks on the southern slope of Mt. Elbrus including Bolshoi Azau, Malyi Azau, and Garabashi glaciers. Two areas of exposed rocks expanded considerably over the last decade, e.g. between Bolshoi Azau and Malyi Azau glaciers (Fig. 5b). In all, eight small ice bodies with a total area of $0.3 \mathrm{~km}^{2}$ had separated from the main glacier massif by 2012 .
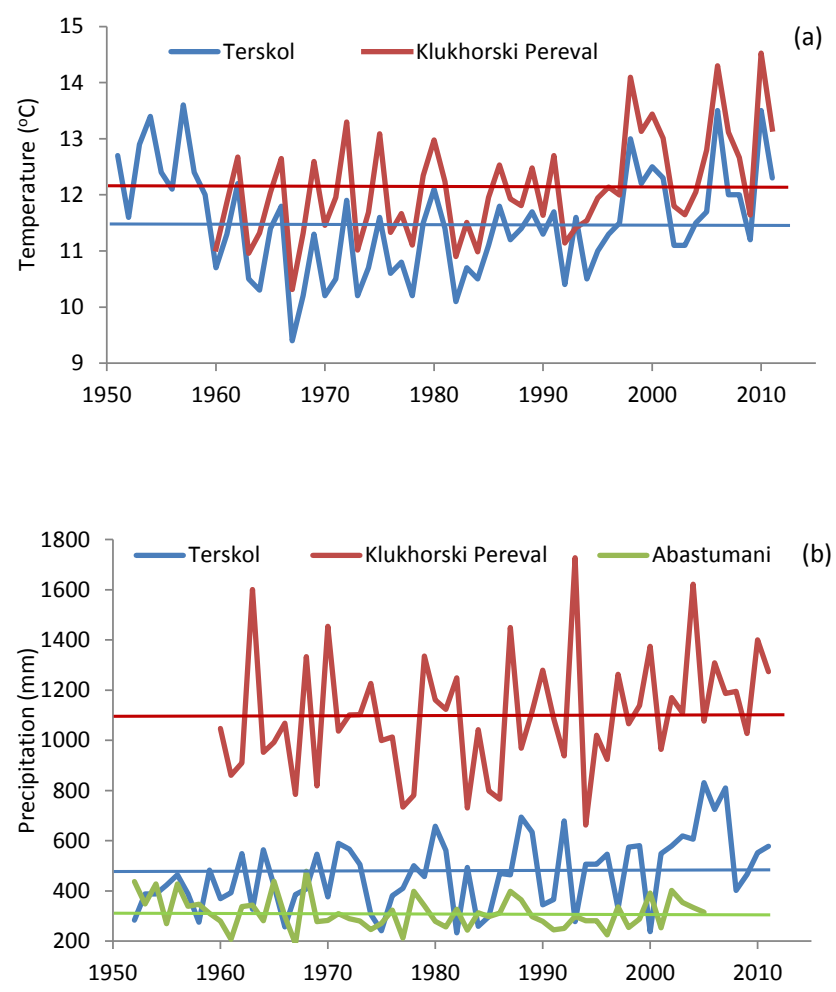

Figure 6. (a) JJA temperature and (b) October-April precipitation for Abastumani, Klukhorski Pereval and Terskol stations. Horizontal lines show record averages for each station.

Changes in areas of individual glaciers are summarized in Table 4. In absolute terms, the Bolshoi Azau and Dzhikiugankez glaciers experienced the largest recession, losing 1.2 and $1.9 \mathrm{~km}^{2}$. In relative terms, two small hanging glaciers (N 311 and 312) located west of the Bolshoi Azau glacier (Figs. 4 and 5) lost the largest proportion of their map area, 15.2 and $15.4 \%$ each, although in absolute terms the loss is small at $0.1 \mathrm{~km}^{2}$. The larger glaciers lost between 1 and $7.4 \%$. Among the larger glaciers, the highest relative loss characterized the Dzhikiugankez ice plateau and the Garabashi and Irikchat glaciers. The area losses of glacier N 317 (Fig. 4), which terminates over a cliff at approximately $4400 \mathrm{~m}$ a.s.l., and glacier N 319 were not detectable. The difference in area loss between glaciers with different aspects is close to the accuracy of measurements for glaciers with southern $(5.6 \%)$, eastern $(5.0 \%)$, and northern $(4.3 \%)$ aspects. The three glaciers with western aspect lost $2.5 \%$ of their areas.

\subsection{Terminus retreat}

Data on retreat of glacier termini are summarized in Table 5. Across the region, terminus retreat increased from the $1987-2000 / 2001$ period to the 2000/2001-2010 period by the factor 2.5-3.8. The highest recession rates of 11$14 \mathrm{~m} \mathrm{yr}^{-1}$ were observed in the central MCR and on Mt. El- 
Table 4. Changes in map areas of glaciers located on Mt. Elbrus between 1999 and 2012. All glaciers are shown in Fig. 4.

\begin{tabular}{|c|c|c|c|c|c|c|}
\hline \multirow{2}{*}{$\begin{array}{l}\text { Number } \\
\text { (Fig. 4) }\end{array}$} & \multicolumn{2}{|c|}{ Glacier } & \multicolumn{2}{|c|}{ Area $\left(\mathrm{km}^{2}\right)$} & \multicolumn{2}{|c|}{ Area change } \\
\hline & Name & WGI ID & 1999 & 2012 & $\mathrm{~km}^{2}$ & $\%$ \\
\hline 1 & Ulluchiran & SU4G08005001 & $11.60 \pm 0.08$ & $11.13 \pm 0.09$ & $0.50 \pm 0.12$ & $4.3 \pm 1.0$ \\
\hline 2 & Karachaul & SU4G08005002 & $7.40 \pm 0.04$ & $7.22 \pm 0.04$ & $0.22 \pm 0.05$ & $3.0 \pm 0.7$ \\
\hline 3 & $\begin{array}{l}\text { Ullukol and } \\
\text { Ullumalienderku }\end{array}$ & SU4G08005003 & $4.85 \pm 0.04$ & $4.54 \pm 0.04$ & $0.31 \pm 0.05$ & $6.4 \pm 1.0$ \\
\hline 4 & Mikelchiran & SU4G08005005 & $5.05 \pm 0.03$ & $4.86 \pm 0.03$ & $0.19 \pm 0.04$ & $3.8 \pm 0.8$ \\
\hline 5 & Dzhikiugankez & SU4G08005006 & $26.12 \pm 0.17$ & $24.22 \pm 0.18$ & $1.90 \pm 0.25$ & $7.3 \pm 1.0$ \\
\hline 6 & Irikchat & SU4G08005018 & $1.41 \pm 0.03$ & $1.31 \pm 0.03$ & $0.10 \pm 0.04$ & $7.1 \pm 2.8$ \\
\hline 7 & Irik & SU4G08005020 & $9.18 \pm 0.08$ & $8.90 \pm 0.08$ & $0.28 \pm 0.11$ & $3.1 \pm 1.2$ \\
\hline 8 & No 25 & SU4G08005025 & $0.60 \pm 0.01$ & $0.56 \pm 0.01$ & $0.04 \pm 0.01$ & $6.7 \pm 1.6$ \\
\hline 9 & Terskol & SU4G08005026 & $7.99 \pm 0.04$ & $7.71 \pm 0.03$ & $0.28 \pm 0.05$ & $3.5 \pm 0.6$ \\
\hline 10 & Garabashi & SU4G08005027 & $3.26 \pm 0.03$ & $3.02 \pm 0.03$ & $0.24 \pm 0.03$ & $7.4 \pm 0.9$ \\
\hline 11 & Malyi Azau & SU4G08005028 & $8.84 \pm 0.07$ & $8.27 \pm 0.08$ & $0.57 \pm 0.10$ & $6.4 \pm 1.1$ \\
\hline 12 & Bolshoi Azau & SU4G08005029 & $19.70 \pm 0.16$ & $18.53 \pm 0.16$ & $1.17 \pm 0.22$ & $5.9 \pm 1.1$ \\
\hline 13 & 311 & SU4H08004311 & $0.46 \pm 0.01$ & $0.39 \pm 0.01$ & $0.07 \pm 0.01$ & $15.2 \pm 2.2$ \\
\hline 14 & 312 & SU4H08004312 & $0.26 \pm 0.01$ & $0.22 \pm 0.01$ & $0.04 \pm 0.01$ & $15.4 \pm 3.8$ \\
\hline 15 & $313^{*}$ & SU4H08004313 & $1.07 \pm 0.03$ & $1.05 \pm 0.03$ & $0.02 \pm 0.04$ & $1.9 \pm 3.7$ \\
\hline 16 & Ullukam* & SU4H08004313 & $0.65 \pm 0.03$ & $0.64 \pm 0.03$ & $0.01 \pm 0.04$ & $1.5 \pm 6.0$ \\
\hline 17 & 317 & SU4H08004317 & $0.55 \pm 0.01$ & $0.55 \pm 0.01$ & $0.00 \pm 0.01$ & $0.0 \pm 1.8$ \\
\hline 18 & Kyukyurtlyu & SU4H08004318 & $6.92 \pm 0.06$ & $6.83 \pm 0.06$ & $0.09 \pm 0.08$ & $1.3 \pm 1.2$ \\
\hline 19 & 319 & SU4H08004319 & $0.46 \pm 0.02$ & $0.46 \pm 0.02$ & $0.00 \pm 0.03$ & $0.0 \pm 6.5$ \\
\hline \multirow[t]{2}{*}{20} & Bityuktyube & SU4H08004320 & $1.98 \pm 0.04$ & $1.90 \pm 0.04$ & $0.08 \pm 0.06$ & $4.0 \pm 3.0$ \\
\hline & $\begin{array}{l}8 \text { separated ice } \\
\text { bodies (Fig. 4) }\end{array}$ & & - & $0.30 \pm 0.00$ & - & - \\
\hline Total & & & $118.4 \pm 1.0$ & $112.6 \pm 1.0$ & $5.8 \pm 1.4 * *$ & $4.9 \pm 1.2$ \\
\hline
\end{tabular}

* Glacier N 313 is a now disconnected part of Ullukam hence the same WGI identification number. ** Including eight separated ice bodies in 2012.

Table 5. Characteristics of glaciers used for measuring snout retreat. The average error terms are \pm 9.9 and $\pm 11 \mathrm{~m}$ for the $1987-2000 / 2001$ and 2000/2001-2010 periods respectively.

\begin{tabular}{|c|c|c|c|c|c|c|c|c|}
\hline \multirow[t]{3}{*}{ Region } & \multirow[t]{3}{*}{ Slope } & \multirow[t]{3}{*}{ No. } & \multirow{2}{*}{\multicolumn{2}{|c|}{ Length $(\mathrm{km})$ as in 1987}} & \multicolumn{4}{|c|}{ Length change } \\
\hline & & & & & \multicolumn{2}{|c|}{$1987-2000 / 2001$} & \multicolumn{2}{|c|}{$2000 / 2001-2010$} \\
\hline & & & Average & Range & $\mathrm{m}$ & $\mathrm{m} \mathrm{yr}^{-1}$ & $\mathrm{~m}$ & $\mathrm{~m} \mathrm{yr}^{-1}$ \\
\hline \multirow[t]{3}{*}{ Central MCR } & All & 21 & 4.2 & $0.8-9.7$ & 52.9 & 3.8 & 106.7 & 11.9 \\
\hline & $\mathrm{N}$ & 7 & 4.6 & $2.8-9.7$ & 77.1 & 5.5 & 121.4 & 13.5 \\
\hline & $\mathrm{S}$ & 14 & 4.0 & $0.8-8.3$ & 40.8 & 2.9 & 99.4 & 11.0 \\
\hline \multirow[t]{3}{*}{ Western MCR } & All & 17 & 2.3 & $0.8-3.6$ & 40.5 & 3.2 & 78.5 & 8.7 \\
\hline & $\mathrm{N}$ & 13 & 2.2 & $0.8-3.6$ & 47.5 & 3.7 & 88.6 & 8.9 \\
\hline & $\mathrm{S}$ & 4 & 2.7 & $1.8-3.3$ & 13.3 & 1.0 & 32.7 & 3.2 \\
\hline Mt. Elbrus & SE & 6 & 7.0 & $2.6-10.2$ & 115.8 & 8.3 & 126.7 & 14.1 \\
\hline
\end{tabular}

brus, where glaciers are larger, with the strongest acceleration on the southern slope of the MCR. The largest total retreat was exhibited by the Bolshoi Azau glacier, located on Mt. Elbrus, which is the second largest glacier in the sample. This glacier lost $500 \mathrm{~m}$, retreating at a steady rate of $22 \mathrm{~m} \mathrm{yr}^{-1}$. The largest glacier in the sample, Lekzyri, located on the southern slope, lost 40 and $200 \mathrm{~m}$ (2.5\% of its 2001 length) in the two periods respectively. Two benchmark glaciers, Djankuat and Garabashi, retreated by 185 and $170 \mathrm{~m}$ in total. Retreat of glacier termini in the western sector was more subdued, especially on the southern slope, where glaciers were receding by $3.2 \mathrm{~m} \mathrm{yr}^{-1}$ in the first decade of the 21 st century. 


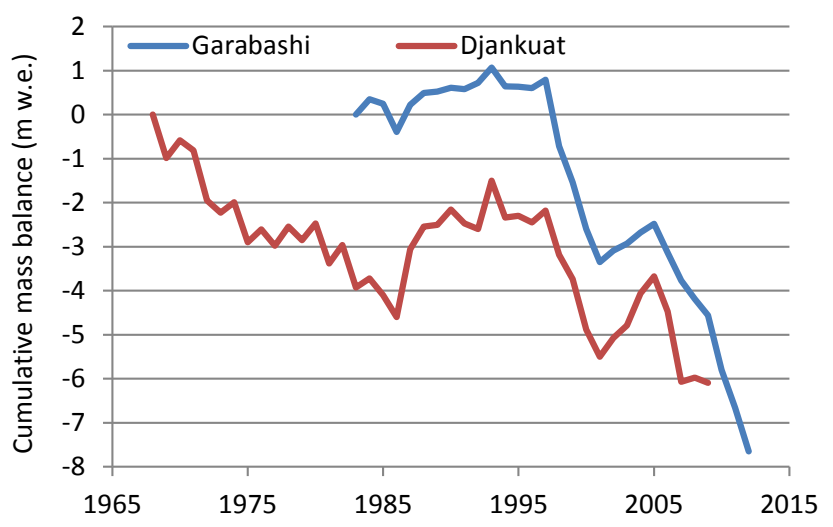

Figure 7. Cumulative mass balance of Garabashi and Djankuat glaciers (WGMS, 2013; unpublished records from the Institute of Geography, Russian Academy of Science for Garabashi in 2012).

\subsection{Climatic variability}

The observed glacier recession is consistent with increasing air temperature of the ablation season (June-JulyAugust; JJA) registered in both the central and western MCR (Fig. 6a). In the central MCR, at Terskol station, the average JJA temperatures in 1987-2001 and 2001-2010 were 11.6 and $11.7^{\circ} \mathrm{C}$ respectively, exceeding the mean JJA temperature of $10.9^{\circ} \mathrm{C}$ registered between 1960 and 1986. Similar trends are observed in the western MCR where the average JJA temperatures at Klukhorski Pereval station in 1987-2001 and 2001-2010 were 12.3 and $12.5^{\circ} \mathrm{C}$ respectively exceeding the 1960-1986 mean JJA temperature of $11.8^{\circ} \mathrm{C}$. The JJA temperature record from Abastumani (not shown) is intermittent and terminates in 2005; however, it correlates closely with the Terskol record $(r=0.90)$ in the overlapping period and indicates strong climatic warming between the 1980s and 2005. It should be noted, however, that despite the warming observed in the last two decades, the 1951-1960 decade still remains the warmest on record in the central MCR with an average JJA temperature of $12.4^{\circ} \mathrm{C}$ (Fig. 6a).

An increase in the accumulation season (October-April) precipitation, statistically significant at $95 \%$ confidence level, was registered at both Terskol and Klukhorski Pereval in the 1987-2010 period, when the averages of 538 and $1173 \mathrm{~mm}$ exceeded the 1960-1986 averages of 427 and $1037 \mathrm{~mm}$ by 26 and $13 \%$ respectively (Fig. 6b). At Terskol, a positive linear trend for the 1951-2011 period was statistically significant. It indicated a $35 \mathrm{~mm}$ increase in the accumulation season precipitation per decade and explained $19 \%$ of the total variance in the data set. By contrast, the accumulation season precipitation did not change at Abastumani in 1987-2005 in comparison with 1960-1986. By 2005, a statistically significant change in precipitation had already occurred on the northern slope at both stations.

\section{Discussion}

In the central and western sectors of the MCR and on Mt. Elbrus, the measured glacier map area reduction in the first decade of the 21 st century of $4.7 \pm 2.1 \%$ exceeded uncertainties associated with image co-registration, delineation of glacier outlines, and presence of debris cover (Table 2). The total mapping error for ASTER imagery was estimated as \pm 2.4 and $\pm 2.7 \%$ for the central and western MCR glaciers respectively and $\pm 1.2 \%$ for Mt. Elbrus. This is lower than errors resulting from the use of Landsat imagery (e.g. Paul et al., 2004; Stokes et al., 2006; Bhambri et al., 2011) and similar to or slightly lower than in other studies utilising ASTER imagery (e.g. Bhambri et al., 2011; Shahgedanova et al., 2012). The difference between this study and other studies using ASTER imagery is due to the limited extent of debris cover, size distribution, and morphology of glaciers in the sample. The supra-glacial debris cover significantly reduces the accuracy of glacier mapping (e.g. Racoviteanu et al., 2008; Bhambri et al., 2011; Paul et al., 2013). However, in the Caucasus Mountains the extent of supra-glacial debris is relatively small, typically accounting for 3-25\% of individual glacier areas (Stokes et al., 2007) although there are exceptions such as Donguz-Orun. Importantly, debris-covered glaciers have clearly identifiable snout margins. Larger errors arise when mapping very small glaciers with map areas below $0.1 \mathrm{~km}^{2}$ (e.g. Shahgedanova et al., 2012), however, only $20 \%$ of the glaciers in the assessed sample were smaller than $0.1 \mathrm{~km}^{2}$ in 2001 and these were mostly cirque glaciers with clearly defined margins.

Although differences between glacier wastage in different sectors of the MCR are close to the measurement uncertainty, it is possible to suggest that glaciers located on the southern slope of the central MCR lost a higher proportion of their area than glaciers in other regions of the Caucasus (5.6 $\pm 2.5 \%$; Table 2). The valley glaciers lost an even higher proportion, $7.4 \%$ (Table 3), which is the highest value in the whole sample. A higher rate of glacier wastage in the south is consistent with the observed trends in precipitation. Negative precipitation anomalies were observed for the southern slope in the 1990s. In the 2000s, precipitation anomalies were positive but lower than in the north (Fig. 6b). These trends are consistent with the impacts of the North Atlantic Oscillation (NAO) on precipitation in southern Europe and the westernmost regions of Asia (Marshall et al., 2001). By contrast, glaciers on the southern slope of the western MCR lost $3.8 \%$ of their area, which is the lowest wastage in the region (Table 2), with valley glaciers losing $2.9 \%$ in the north and $3.6 \%$ in the south (Table 3). It is likely that high accumulation-season precipitation, exceeding that in the central MCR by the factor of 2-3 (Volodicheva, 2002), and persistent positive precipitation anomalies observed since the mid-1990s, slowed down glacier retreat in the western MCR.

The glaciers on Mt. Elbrus lost the same percentage of their combined area as glaciers in the central MCR despite 
the higher AAR (Table 2). We calculated the area reduction as $4.9 \pm 1.2 \%$ with a rate of decrease of $0.4 \% \mathrm{yr}^{-1}$ between 1999 and 2012. Zolotarev and Kharkovets (2012), who assessed glacier area change on Mt. Elbrus in the 1997-2007 period using aerial photography from 1997 and Cartosat-1 imagery with spatial resolution of $2.5 \mathrm{~m}$, reported an overall $3.8 \%$ area loss. The difference between the two assessments is small and, in addition to measurement uncertainties, reflects slightly different periods of assessments and interpretation of nunataks and bare rocks as glacierized area by Zolotarev and Kharkovets (2012). Holobaca (2013) reported area change of $9.1 \%$ between 1985 and $2007\left(0.4 \% \mathrm{yr}^{-1}\right)$ from Landsat TM imagery, which is the same as in our assessment.

The average rate of terminus recession of valley glaciers doubled in the north and more than tripled in the south in the 21 st century in comparison with 1987-2001. Using the approximation by Jóhanesson et al. (1989) based on a ratio between glacier depth at ELA and mass balance near the glacier terminus, dynamic response times of Djankuat and Garabashi glaciers are estimated as $12-15$ and $17-18$ years respectively. The observed glacier recession and its acceleration in the last decade detected from the changes in the rate of snout retreat are consistent with the positive trend in summer air temperatures since the 1990s. Strong positive anomalies of $2{ }^{\circ} \mathrm{C}$ in 2006 and 2010 (Fig. 6a) contributed to enhanced glacier melt (Fig. 7). The exceptional heat wave which developed over European Russia in July-August 2010 (Grumm, 2011) was as detrimental for the state of the Caucasus glaciers as the 2003 western European heat wave was for the glaciers in the Alps (Haeberli et al., 2007). The mass balance records for Garabashi show that in the summer of 2010 alone, the glacier lost $2.52 \mathrm{~m}$ w.e., close to the record loss of $2.58 \mathrm{~m}$ w.e. in the El Niño year of 1998 and nearly twice the long-term average (1984 to current). A strong decline in cumulative mass balance (Fig. 7) occurred after 1998 despite a $20 \%$ increase in precipitation (Fig. 6b) north of MCR (WGMS, 2013).

Glacier shrinkage in the Caucasus Mountains appears to be slower than in the European Alps. Paul et al. (2004) reported $18 \%\left(1.3 \% \mathrm{yr}^{-1}\right)$ glacier shrinkage in the Swiss Alps in the 1985-1999 period. Fischer et al. (2014) reported $33 \%$ $\left(1.1 \% \mathrm{yr}^{-1}\right)$ and $11 \%\left(1.3 \% \mathrm{yr}^{-1}\right)$ shrinkage for the eastern Swiss Alps for the 1973-2003 and 2003-2009 periods respectively. Maragno et al. (2009) reported $5.5 \%\left(1.4 \% \mathrm{yr}^{-1}\right)$ shrinkage in 1999-2003 and even stronger shrinkage of 11 or $2.8 \% \mathrm{yr}^{-1}$ was reported by Diolaiuti et al. (2011) for the Italian Alps. The heat wave of 2003 had a strong impact on glacier wastage in the European Alps (Haeberli et al., 2007), however, even prior to this extreme event, glacier wastage rates in the Alps exceeded those of $0.4-0.6 \% \mathrm{yr}^{-1}$ that we report for the Caucasus. Another important difference is contribution of small glaciers to the overall reduction of glacierized area. Thus in the Swiss and Lombardy Alps, glaciers with individual areas less than $1 \mathrm{~km}^{2}$ contributed about 40 and $58 \%$ of total area loss while accounting for only 15 and $30 \%$ of glacierized area respectively (Paul et al., 2004; Citterio et al., 2007). Glaciers of the same size category occupied $22.3 \%$ of the glacierized area in MCR and contributed $7.3 \%$ of area loss. Topographic effect and geographical distribution of glaciers are the most likely explanation. Larger glaciers are valley glaciers, whose tongues open to sunlight exhibit a stronger retreat. Smaller glaciers are mostly cirque glaciers, whose recession is restricted by topography and shading provided by the cirque walls. Slower wastage of small cirque glaciers due to the shading effect was reported by Shahgedanova et al. (2012) for the polar Urals. In the central MCR, the difference is more pronounced than in the western sector because larger valley glaciers are located on the southern slope where negative precipitation anomalies contributed to stronger glacier retreat (Table 3).

\section{Conclusions}

To conclude, (i) the Caucasus glaciers lost $4.7 \pm 2.1 \%$ of their total area between 2000 and 2010/2012 and the estimate exceeds the uncertainty of the measurements; (ii) glaciers of Mt. Elbrus lost a similar proportion of their area to that lost by the glaciers located in the MCR despite higher elevation and large AAR; (iii) the largest wastage occurred on the southern slope of the central sector in line with precipitation anomalies; (iv) the retreat of glacier termini accelerated in the first decade of the 21 st century in comparison with the end of the 20th century.

Acknowledgements. We are grateful to the reviewers, G. Cogley and R. Bhambri, and to the editor, T. Bolch, for the very detailed comments which helped to improve the paper.

Edited by: T. Bolch

\section{References}

Andreassen, L. M., Paul, F., Kääb, A., and Hausberg, J. E.: Landsatderived glacier inventory for Jotunheimen, Norway, and deduced glacier changes since the 1930s, The Cryosphere, 2, 131-145, doi:10.5194/tc-2-131-2008, 2008.

Bhambri, R., Bolch, T., Chaujar, R. K., and Kulshreshtha S. C.: Glacier changes in the Garhwal Himalaya, India, from 1968 to 2006 based on remote sensing, J. Glaciol., 57, 543-556, 2011.

Bhambri, R., Bolch, T., and Chaujar, R. K.: Frontal recession of Gangotri Glacier, Garhwal Himalayas, from 1965-2006, measured through high resolution remote sensing data, Current Sci., 102, 489-494, 2012.

Bolch, T., Buchroithner, M. F., Pieczonka, T., and Kunert, A.: Planimetric and volumetric glacier changes in the Khumbu Himalaya 1962-2005 using Corona and ASTER data, J. Glaciol., 54, 562600, 2008. 
Bolch, T., Menounos, B., and Wheate, R.: Landsat-based inventory of glaciers in western Canada, 1985-2005, Remote Sens. Environ., 114, 127-137, 2010.

Borovik, E. S. and Kravtsova, V. I.: Catalogue of Glaciers of the USSR, Gidrometeoizdat, Leningrad, Vol. 8, Part 5, Basins of the Malka and the Baksan Rivers, 86 pp., 1970 (in Russian).

Bushueva, I. S. and Solomina, O. N.: Kolebaniya lednika Kashkatash v XVII-XX1 vv. po kartograficheskim, dendrohronologicheskim i lichonometricheskim dannym (Fluctuations of Kashakatash Glacier in XVII-XXI centuries according to cartographic, dendrochronological and lichonometric data). Led $\mathrm{i}$ Sneg (Ice and Snow), 2 (118), 121-130, 2012 (in Russian).

Church, J. A., White, N. J., Konikow, L. K., Domingues, C. M., Cogley, J. G., Rignot, E., Gregory, J. M., van den Broeke, M. R., Monaghan, A. J., and Velicogna, I.: Revisiting the Earths sealevel and energy budgets from 1961 to 2008 , Geophys. Res. Lett., 38/, L18601, doi:10.1029/2011GL048794, 2012.

Citterio, M., Diolaiuti, G., Smiraglia, C., D’Agata, C., Carnielli, T., Stella, G., and Siletto, G. B.: The fluctuations of Italian glaciers during the last century: A contribution to knowledge about Alpine glacier changes, Geogr. Annal. A, 89 A, 167-184, 2007.

DeBeer, C. M. and Sharp, M. J.: Recent changes in glacier area and volume within the Southern Canadian Cordillera, Ann. Glaciol., 46, 215-221, 2007.

Diolaiuti, D., Maragno, D., D’Agata, C., Smiraglia,C., and Bocchiola, D.: Glacier retreat and climate change: Documenting the last 50 years of Alpine glacier history from area and geometry changes of Dosde Piazzi glaciers (Lombardy Alps, Italy), Prog. Phys. Geog., 35, 161-182, 2011.

Dolgova, E. A., Matskovsky, V. V., Solomina, O. N., Rototaeva, O. V., Nosenko, G. A., and Khmelevsky, I. F.: Reconstructing mass balance of Garabashi Glacier (1800-2005) using dendrochronological data, Led i Sneg (Ice and Snow), 1, 34-43, 2013 (in Russian).

Dyurgerov, M. B. and Meier, M. F: Twentieth century climate change: evidence from small glaciers, P. Natl. Acad. Sci. USA, 97, 1406-1411, 2000.

Frey, H., Paul, F., and Strozzi, T.: Compilation of a glacier inventory for the western Himalayas from satellite data: methods, challenges, and results, Remote Sens. Environ., 124, 832-843, 2012.

Fischer, M., Huss, M., Barboux, C., and Hoelzle, M.: The new Swiss Glacier Inventory SGI2010: Relevance of using highresolution source data in areas dominated by very small glaciers, Arct. Antarct. Alp. Res., 46, 933-945, 2014.

Granshaw, F. D. and Fountain, A. G.: Glacier change (1958-1998) in the North Cascades National Park Complex, Washington, USA, J. Glaciol., 52, 251-256, 2006.

Grumm, R. H.: The Central European and Russian heat event of July-August 2010, B. Am. Meteorol. Soc., 92, 1285-1296, 2011.

Haeberli, W., Hoelzle, M., Paul, F., and Zemp, M.: Integrated monitoring of mountain glaciers as key indicators of global climate change: the European Alps, Ann. Glaciol., 46, 150-160, 2007.

Hall, D. K., Bayr, K. J., Schöner, W., Bindschadler, R. A., and Chein, J. Y. L.: Consideration of the errors inherent in mapping historical glacier positions in Austria from the ground and space (1983-2001), Remote Sens. Eviron., 86, 566-577, 2003.
Hoelzle, M., Haeberli, W., Dischl, M., and Peschke, W.: Secular glacier mass balances derived from cumulative glacier length changes, Global Planet. Change, 36, 295-306, 2003.

Holobaca, I.-H: Glacier Mapper - a new method designed to assess change in mountain glaciers, Int. J. Remote Sens., 34, 8475 8490, 2013.

IPCC 2013: Climate Change 2013: The Physical Science Basis. Contribution of Working Group I to the Fifth Assessment Report of the Intergovernmental Panel on Climate Change, edited by: Stoker, T. F., Qin, D., Plattner, G.-K., Tignor, M., Allen, S. K., Boschung, J., Nauels, A., Xia, Y., Bex, V., and Midgley, P. M., Cambridge University Press, Cambridge, 1535 pp., 2013.

Jóhannesson, T., Raymond, C., and Waddington, E.: Time-scale for adjustment of glaciers to changes in mass balance, J. Glaciol., 35, 355-369, 1989.

Keinholz, C., Hock, R., and Arendt, A. A.: A new semi-automatic approach for dividing glacier complexes into individual glaciers, J. Glaciol., 59, 925-937, 2013.

Koblet, T., Gärtner-Roer, I., Zemp, M., Jansson, P., Thee, P., Haeberli, W., and Holmlund, P.: Reanalysis of multi-temporal aerial images of Storglaciären, Sweden (1959-99) - Part 1: Determination of length, area, and volume changes, The Cryosphere, 4, 333-343, doi:10.5194/tc-4-333-2010, 2010.

Kutuzov S., Lavrentiev, I. I., Macheret, Yu, Ya., and Petrakov, D. A.: Changes of Marukh Glacier from 1945 to 2011 Led i Sneg (Ice and Snow), 1, 123-128, 2012 (in Russian).

Lang, H. R. and Welch, R.: ATBD-AST-08 Algorithm theoretical basis document for ASTER digital elevation models (Standard product AST14), available at: http://eospso.gsfc.nasa.gov/eos_ homepage/for_scientists/atbd/docs/ASTER/atbd-ast-14.pdf, (last access: 7 July 2014), 1999.

Leclercq, P. W. and Oerlemans, J.: Global and hemispheric temperature reconstruction from glacier length fluctuations, Clim. Dynam., 38, 1065-1079, 2012.

Leclercq, P. W., Oerlemans, J., Basagic, H. J., Bushueva, I., Cook, A. J., and Le Bris, R.: A data set of worldwide glacier length fluctuations, The Cryosphere, 8, 659-672, doi:10.5194/tc-8-6592014, 2014.

Maragno, D., Diolaiuti, G., D’Agata, C., Mihalcea, C., Bocchiola, D., Janetti, E. B., Riccardi, A., and Smiraglia, C.: New evidence from Italy (Adamello Group, Lombardy) for analyzing the ongoing decline of Alpine glaciers, Geograf. Fis. Dinam. Quaternaria, 32, 31-39, 2009.

Marshall, J., Kushnir, Y., Battisti, D., Chang, P., Czaja, A., Dickson, R., Hurrell, J., McCartney, M., Saravanan, R., and Visbeck, M.: North Atlantic climate variability: phenomena, impacts and mechanisms, Int. J. Climatol., 21, 1863-1898, 2001.

Maruashvili, L. I., Kurdgelaidze, G. M., and Lashkhi, T. A.: Catalogue of Glaciers of the USSR, Vol. 9, Parts 2-6, Basin of the Kodori and Inguri Rivers, Gidrometeoizdat, Leningrad, 86 pp., 1975 (in Russian).

Meyer, D., Tachikawa, T., Kaku, M., Iwasaki, A., Gesch, D., Oimoen, M., Zhang, Z., Danielson, J., Krieger, T., Curtis, B., Haase, J., Abrams, M., Crippen, R., and Carabajal, C.: ASTER Global Digital Elevation Model Version 2 - Summary of Validation Results, NASA Land Processes Distributed Active Archive Center, online report, 26 pp., available at: http://www.jspacesystems.or.jp/ersdac/GDEM/ver2Validation/ 
Summary_GDEM2_validation_report_final.pdf (last access: 7 July 2014), 2011.

Nakano, K., Zhang, Y., Shibuo, Y., Yabuki, H., and Hirabayashi, Y.: A monitoring system for mountain glaciers and ice caps using 30 meter resolution satellite data, Hydrol. Res. Lett., 7, 73-78, 2013.

Panov, V. D.: Evolyutsiya sovremennogo oledeneniya Kavkaza (Evolution of the Contemporary Glaciation in the Caucasus), Gidrometeoizdat. St. Petersburg, 432 pp., 1993 (in Russian).

Panov, V. D. and Kravtsova, V. I.: Catalogue of Glaciers of the USSR, Vol. 8, Parts 1-4, Basin of the Kuban River, Girdometeoizdat, Leningrad, 145 pp., 1967 (in Russian).

Paul, F. and Andreassen, L. M.: A new glacier inventory for the Svartisen region, Norway, from Landsat ETM+ data: challenges and change assessment, J. Glaciol., 55, 607-618, 2009.

Paul, F., Kääb, A., Maisch, M., Kellenberger, T., and Haeberli, W.: The new remote-sensing-derived Swiss glacier inventory: I. Methods, Ann. Glaciol., 34, 355-361, 2002.

Paul, F., Kääb, A., Maisch, M., Kellenberger, T., and Haeberli, W.: Rapid disintegration of Alpine glaciers observed with satellite data, Geophys, Res. Lett., 31, L21402, 10.1029/2004GL020816, 2004.

Paul, F., Barry, R., Cogley, G., Frey, H., Haeberli, W., Ohmura, A., Ommanney, S., Raup, B., Rivera, A., and Zemp, M.: Recommendations for the compilation of glacier inventory data from digital sources, Ann. Glaciol., 50, 119-126, 2009.

Paul, F., Barrand, N. E., Baumann, S., Berthier, E., Bolch, T., Casey, K., Frey, H., Joshi, S. P., Konovalov, V., Le Bris, R., Mölg, N., Nosenko, G., Nuth, C., Pope, A., Racoviteanu, A., Rastner, P., Raup, B., Scharrer, K., Steffen, S., and Winsvold, S: On the accuracy of glacier outlines derived from remote-sensing data, Ann. Glaciol., 54, 171-182, 2013.

Popovnin, V. V.: Pole akkumulyatsii gornogo lednika (Accumulation Zone of a Mountain Glacier), Mater. Glyatsiol. Issled., (Data Glaciol. Res.), 88, 27-40, 2000 (in Russian).

Popovnin, V. V. and Petrakov, D. A.: Lednik Djankuat za poslednie 34 goda, 1967/68-2000/01 (Djankuat Glacier in the last 34 years, 1967/68-2000/01), Mater. Glyatsiol. Issled., (Data Glaciol. Res.), 98, 167-175, 2005 (in Russian).

Racoviteanu, A. E., Williams, M. W., and Barry, R. G.: Optical Remote Sensing of Glacier Characteristics: A Review with Focus on the Himalaya, Sensors, 8, 3355-3383, 2008.

Rototaeva, O.: Data on surging glaciers in the Northern Caucasus, in: Oledenenie Severnoi i Tsentralnoi Evrazii v Sovremennuyu Epohu (Glaciation in Northern and Central Eurasia at Present Time), edited by: Kotlyakov, V. M., Nauka Publishers, Moscow, 215-223, 2006 (in Russian).

Rototaeva, O., Nosenko, G., Tarasova, L., and Khmelevsky, I.: Caucasus, in: Oledenenie Severnoi i Tsentralnoi Evrazii v Sovremennuyu Epohu (Glaciation in $\mathrm{N}$ orthern and Central Eurasia at Present Time), edited by: Kotlyakov, V. M., Nauka Publishers, Moscow, 141-162, 2006 (in Russian).
Schiefer, E., Menounos, B., and Wheate, R. D.: An inventory and morphometric analysis of British Columbia glaciers, Canada, J. Glaciol., 54, 551-560, 2008.

Shahgedanova, M., Stokes, C. R., Gurney, S. D., and Popovnin, V. V.: Interactions between mass balance, atmospheric circulation and recent climate change on the Djankuat glacier, Caucasus Mountains, Russia, J. Geophys. Res.-Atmos., 110, D04108, doi:10.1029/2004JD005213, 2005.

Shahgedanova, M., Popovnin, V., Aleynikov, A., Petrakov, D., and Stokes, C. R.: Long-term change, inter-annual, and intraseasonal variability in climate and glacier mass balance in the central Greater Caucasus, Russia, Ann. Glaciol., 46, 355-361, 2007.

Shahgedanova, M., Nosenko, G., Bushueva, I., and Ivanov, M.: Changes in area and geodetic mass balance of small glaciers, Polar Urals, Russia, 1950-2008, J. Glaciol., 58, 953-964, 2012.

Stokes, C. R., Gurney, S. D., Shahgedanova, M., and Popovnin, V. V.: Late-20th-century changes in glacier extent in the Caucasus Mountains, Russia/Georgia, J. Glaciol., 52, 99-109, 2006.

Stokes, C. R., Popovnin, V. V., Aleynikov, A., and Shahgedanova, M.: Recent glacier retreat in the Caucasus Mountains, Russia, and associated changes in supraglacial debris cover and supra/proglacial lake development, Ann. Glaciol., 46, 196-203, 2007.

Svoboda, F. and Paul, F.: A new glacier inventory on southern Baffin Island, Canada, from ASTER data: I. Applied methods, challenges and solutions, Ann. Glaciol., 50, 11-21, 2009.

Volodicheva, N.: The Caucasus, in: The Physical Geography of Northern Eurasia, edited by: Shahgedanova, M., 350-376, Oxford University Press, Oxford, 2002.

WGMS: Glacier Mass Balance Bulletin No. 12 (2010-2011) and earlier issues edited by: Zemp, M., Nussbaumer, S. U., Gärtner-Roer, I. I., Hoelzle, M., Paul, F., and Haeberli, W., ICSU(WDS)/IUGG (IACS)/UNEP/WMO. World Glacier Monitoring Service, Zurich, Switzerland, 106 pp., 2013.

Yefremov, Yu. V., Panov, V. D., Lurie, P. M., Iliychev, Yu. S., Panova, S. V., and Lutkov, D. A.: Orografiya, oledenenie, klimat Bolshogo Kavkaza (Orography, Glaciation and Climate of the Greater Caucasus), Kubanskyi State University Press, Krasnodar, 337 pp., 2007 (in Russian).

Zemp, M., Hoelzle, M., and Haerberli, W.: Six decades of glacier mass-balance observations: a review of the worldwide monitoring network, Ann. Glaciol., 50, 101-111, 2009.

Zolotarev, E. A. and Kharkovets, E. G.: Oledenenie Elbrusa kontse XX veka (Glaciation of Mt. Elbrus at the end of the 20th Century), Led i Sneg (Ice and Snow), 5, 45-51, 2007 (in Russian).

Zolotarev, E. A. and Kharkovets, E. G.: Evolyutsiya oledeneniya Elbrusa posle malogo lednikovogo perioda (Evolution of glaciation on Mt Elbrus after the Little Ice Age), Led i Sneg (Ice and Snow), 2, 5-14, 2012 (in Russian). 